\title{
Experimental Study of Two-dimensional Migration and Distribution of Non-Aqueous Phase Liquid in Unsaturated and Saturated Porous Media
}

\author{
Kazuei ISHII * , Tohru FURUICHI * and Nobutoshi TANAKA *
}

\section{不飽和・飽和多孔体中における難水溶性有機化合物原液の 二次元移動と分布に関する実験的研究}

\author{
石井一英*·古市 徹* ·田中信壽*
}

\begin{abstract}
To elucidate the two-dimensional migration and distribution of non-aqueous phase liquids (NAPLs) in soils, downward migration and lateral spreading of pure 1,1,1trichloroethane (TCA) and toluene through a layer of glass beads was observed. In particular, the behavior of both fluids in the unsaturated zone and in the vicinity of a water table was investigated, by considering mass balances (residual NAPL distributions, dissolution and volatilization). In a 24-hour experiment, about $21 \%$ to $24 \%$ of TCA (50 $\mathrm{mL}$ ) volatilized, 0.4 to $2 \%$ dissolved, and about $75 \%$ remained as pure liquid in the layer of glass beads. In a 24-hour experiment, about $5 \%$ of toluene $(50 \mathrm{~mL})$ volatilized, 0.02 to $0.2 \%$ dissolved, and about $95 \%$ remained as pure liquid. The amount of pure TCA remaining above a water table (in the unsaturated zone and saturated capillary zone), which apparently acts as a barrier for NAPL infiltration, reached 30 to $48 \%$. Lateral spreading of pure TCA above the water table was found to be very small and negligible. A further experiment simulating groundwater fluctuations suggested that pure toluene, even if its migration has stopped, would be transported downgradient again when a water table falls.
\end{abstract}

Key Words: soil and groundwater contamination, non-aqueous phase liquid (NAPL), two-

* Division of Environment Resource Engineering, Graduate School of Engineering, Hokkaido University 北海道大学大学院工学研究科環境資源工学専攻 
dimensional migration, distribution of residual NAPL, volatilization and dissolution

\section{要 旨}

1,1,1-トリクロロエタン（TCA）及びトルエンのガラスビーズ層内での二次元移動現象 を観察した。特に、不飽和带と地下水面付近での両液体の挙動を、残余飽和度分布、揮 発、溶解現象を考慮して検討した。物質収支の結果としては、注入量 $50 \mathrm{~mL}$ の場合、21 $24 \%$ TCA が揮発し、0.4 $2 \%$ が溶解し、そして $75 \%$ が原液としてビーズ層内に存在し た。一方、トルエンの場合は $5 \%$ が揮発し、0.02 0.2\%が溶解し、そして $95 \%$ が原液と して存在した。地下水面上に存在する TCA は、30４8\%に達したが、地下水面上方での TCAの横への広がりは小さく無視できることが分かった。また、地下水面が下降する時 にトルエンの高飽和度領域が、下流方向へ移動することが分かった。

\section{キーワード：土壤・地下水污染、難水溶性有機化合物 (NAPL)、二次元移動、残余 NAPL 分布、揮発・溶解}

\section{Introduction}

Soil and groundwater contamination caused by chlorinated organic compounds such as trichloroethylene (TCE), and petroleum products like benzene is an environmental problem. Such compounds are known as non-aqueous phase liquids (NAPLs), because they are immiscible with water. When a NAPL is introduced into the subsurface zone due to accidental leakage of storage tanks or illegal dumping, it migrates downward through the soil layers as a separate phase, which means that three phases (water, NAPL and air) may exist in pores. Some NAPL can then reach the water table of unconfined aquifer depending on the size of the mass released and hydrogeological conditions. Light NAPL (LNAPL), which is lighter than water, generally stagnates as a continuous mass of NAPL (LNAPL pool) at the water table and migrates along a hydrological gradient, and whereas dense NAPL (DNAPL), which is denser than water, penetrates below the water table, migrates downwards through an aquifer, and may form a DNAPL pool above some impermeable layers (Schwille, 1975, 1981, 1988). At the same time, some NAPLs leave a trail of immobile NAPL (residual NAPL), which is trapped in pores by capillary forces (Schwille, 1975, 1981, 1988). These continuous and residual NAPL cause long-term groundwater contamination because they dissolve into water very slowly. To remedy such contamination, it is necessary to estimate their distribution in these various states and to remove them from the subsurface.

NAPL migration in the subsurface is affected by: (1) volume of NAPL released, (2) area of infiltration, (3) duration of release, (4) properties of the NAPL, (5) properties of the media, and (6) subsurface flow conditions (Feenstra and Cherry, 1988 as quoted in Mercer and Cohen, 1990). With respect to NAPL vertical migration, Schwille (1975, 1981, 1988) reported that DNAPL penetrates a water table as described above. However, Hirata \& Muraoka (1988) re- 
ported by one-dimensional experiments that some portion of the TCE remained above the water table. In addition, Ishii et al. (1995, 1998) also showed that some portion of a DNAPL, such as TCE, 1,1,1-trichloroethane (TCA), or bromoform remained above a water table.

Further, with respect to lateral spreading, Schwille (1988) suggested that a width of NAPL plume was approximately equal to that of the original spill at the surface, implying that the NAPL plume does not spread laterally much in either the unsaturated or saturated zones. However, under heterogeneous geological conditions, for example where impermeable lenses, etc., exists, it has been shown that the lateral spreading of NAPLs may be significant (Kueper et al., 1989; Pantazidou \& Sitar, 1993; Illangasekare et al., 1995a).

Schwille (1988) showed that tetarachloroethylene (PCE) plume was not affected by groundwater flow rate for hydrologic conductivity $k=3 \times$ $10^{-5} \mathrm{~cm} / \mathrm{s}$, and hydraulic gradient $i=0.005$. In addition, Hunt et al. (1988) suggested on theoretical consideration that residual NAPL in pores would not be moved under normal groundwater flow conditions. Schwille (1975, 1981) showed that LNAPL lying on a water table migrated along a hydraulic gradient, and Illangasekare \& Yates (1995b) obtained experimental data from such a case. When the water table fell, LNAPL was redistributed, whreas, when the water table rose, some LNAPL also rose, and some was trapped (Schwille, 1981). Pantazidou \& Sitar (1993) showed that when the water table rose, an LNAPL plume could become wider. In addition, Yagi et al. (1996) reported on some one-dimensional experiments with glass beads (particle size: $1 \mathrm{~mm}$ and $3 \mathrm{~mm}$ ), which suggested that pure TCE migrated downward when the water table fell, but did not migrate upwards when the water table rose.

As described above, with respect to vertical migration of NAPL, it has been reported that some DNAPL stagnates above a water table, and they may migrate downwards later when the water table falls. On the other hand, with respect to horizontal migration, it has been shown that DNAPL spreads above impermeable lenses and is not affected by groundwater flow. However, it has not yet been determined whether DNAPL spreads above a water table, specifically in the saturated capillary and unsaturated capillary zones (the definitions are described in Section 3 below), which are believed to act as a barrier against DNAPL infiltration. The lateral spreading of DNAPL above a water table therefore needs to be examined with two-dimensional experiments. In addition, in the case where a water table fluctuates, the vertical migration of NAPL has been already studied, but there has been insufficient study to adequately clarify the potential for horizontal migration.

Many researchers have developed mathematical models of NAPL behavior in the subsurface, and these can be divided into two types: a capillary model and a compositional model. The former type ignores interfacial mass transfer processes such as dissolution into the aqueous phase and volatilization into the gaseous phase (Faust, 1985, Osbone \& Sykes, 1986; Kuppusamy et al., 1987; Faust et al., 1989; Kia, 1991; Kueper \& Frind, 1991a, 1991b; Kaluarachchi \& Parker, 1992), and the latter type considers the interfacial mass transfer processes (Abriola \& Pinder, 1985a, 1985b; Pinder \& Abriola, 1986; Sleep \& Sykes, 1993a, 1993b). Moreover, models that consider heat transfer have been also developed (Adenekan \& Patzek, 1993; Wang \& Cheng, 1996; Cheng \& Wang, 1996). However, comparisons between calculated and observed values have been limited. For LNAPLs, Eckberg \& Sunada (1984), Lenhard et al. (1988), Cary et al. (1989) and Oostrom \& Lenhard (1998) evaluated their one-dimensional capillary models. In addition, Host-Madeson \& Hogh-Jensen (1992), Thiez \& Ducreux (1994), Van Geel \& Sykes 
(1997) and Schroth et al. (1998a, 1998b) tested two-dimensional capillary models. Each study showed good agreement between calculated and observed values. For DNAPLs, tests have only been conducted for the saturated zone (Kueper \& Frind, 1991a, 1991b; Oostrom et al., 1999). As noted, the capillary model has been tested, but a compositional model that considers dissolution and volatilization processes has not been tested. Furthermore, DNAPL migration, especially its stagnation in saturated capillary and unsaturated capillary zones, has not been examined.

With respect to dissolution and volatilization, Miller et al. (1990), Powers et al. (1992), Imhoff et al. (1993), and Powers et al. (1994) developed non-equilibrium models for mass transfer between a NAPL and a water phase, and determined key parameters experimentally. Oostrom et al. (1999) examined a "pool model" which had been proposed by Hunt et al. (1988). Falta et al. (1989), Sleep \& Sykes (1989), and Mendoza \& Frind (1990a, 1990b) conducted numerical analyses of volatilization by considering the density-driven flow effect. Moreover, Wilkins et al. (1995) determined parameters for non-equilibrium models of mass transfer between NAPL and the gas phase. As described above, although each phenomenon such as NAPL migration, dissolution or volatilization has been studied inde- pendently, there have been few studies of the overall situation, which considers a mass balance of NAPL.

Therefore, in the present study, two-dimensional infiltration experiments were conducted, which considered a mass balance of NAPL. In particular, the influences of infiltration rate, period of injection, and properties of the NAPL on NAPL migration in an unsaturated zone, were investigated. In addition, lateral spreading in the saturated capillary and unsaturated capillary zones was examined. The effect of groundwater flow and water table fluctuations on vertical and horizontal migration of NAPL was also observed.

\section{Experimental method}

In the present study, pure TCA and toluene were used, the characteristics of which are shown in Table 1. TCA is a representative of a DNAPL, and toluene of a LNAPL. Because they are transparent liquids, an organic dye (Sudan $\mathrm{IV}$; at a concentration of $1 \mathrm{mg} / \mathrm{mL}$ ) was used to color them to make their migration visible.

The experimental apparatus is shown in Fig. 1. It has glass plates on both the front and back to allow visual observation and the remaining parts are made of stainless steel. The experimental procedures were as follows.

Table 1 Characteristics of NAPLs used in the present study

\begin{tabular}{lrr}
\hline \multicolumn{1}{c}{ NAPL } & $\begin{array}{c}1,1,1-\text { Trichloroethane } \\
\text { (TCA) }\end{array}$ & Toluene \\
\hline specific gravity [-] & 1.338 & 0.866 \\
viscosity [mPa·s] & 0.795 & 0.586 \\
kinematic viscosity $\left[\mathrm{mm}^{2} / \mathrm{s}\right]$ & 0.594 & 0.677 \\
surface tension[mN/m] & & \\
$\quad$ with air & 25.6 & 28.4 \\
$\quad$ with water & 45.0 & 36.3 \\
solubility [mg/L- $\left.\mathrm{H}_{2} \mathrm{O}\right]\left(0^{\circ} \mathrm{C}\right)$ & $1260^{*}$ & 515 \\
vapor pressure[mmHg] $\left(20^{\circ} \mathrm{C}\right)$ & 100 & 22 \\
* USEPA(1989) & &
\end{tabular}




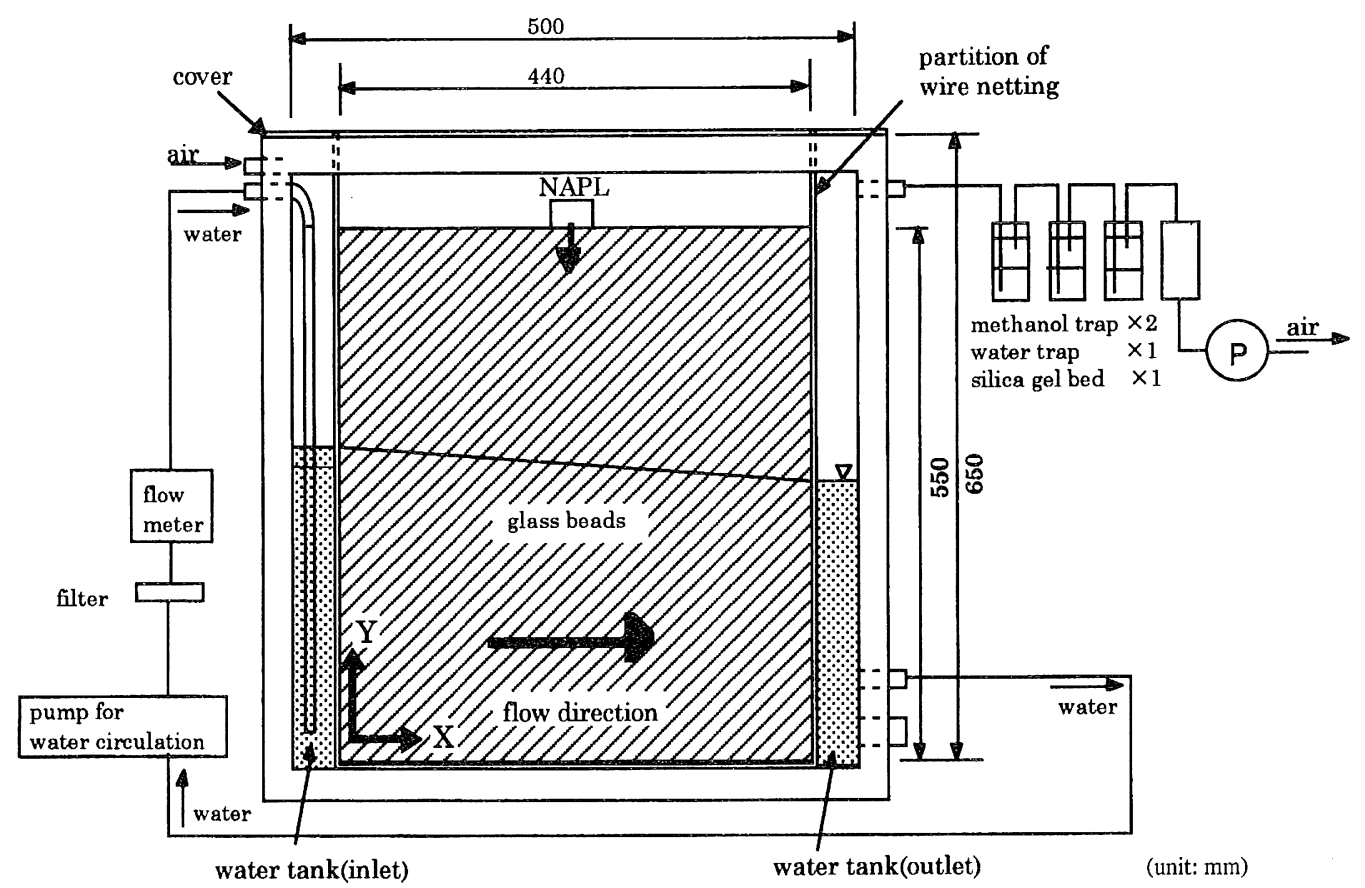

Fig. 1 An apparatus for two-dimensional experiment

(1) The surfaces of the glass beads (the particle size was $0.5-0.7 \mathrm{~mm}$ ) were cleaned with an alkaline detergent. The glass beads were then packed between partitions of wire netting in stages to a depth of $5 \mathrm{~cm}$ at a time. Each stage was saturated with water, and compacted with a rod to eliminate air bubbles. By repeating these staged operations, a fully saturated glass beads layer was built up. The saturated hydraulic conductivity of the layer and porosity were approximately 0.25 $\mathrm{cm} / \mathrm{s}$ and 0.36 by volume, respectively.

(2) Groundwater flow was simulated by circulation of water through the layer. The water table level was adjusted as appropriate. The circulation rate was measured with a flow meter. In the stagnant condition experiment, water was not circulated through the apparatus.

(3) After 1 to 1.5 days, NAPL was injected from the center and top of the glass beads layer. Two methods for NAPL injection were used. One was to inject 20 to $100 \mathrm{~mL}$ of NAPL with a rectangular funnel as shown in Fig. 2 (method A). The other was to inject NAPL, using a stainless steel tube with a diameter of about $2 \mathrm{~mm}$, at a constant rate of about $1 \mathrm{~mL} / \mathrm{min}$ by pumping $(\operatorname{method} \mathrm{B})$. Migration of the NAPL plume through the layer was recorded with a video camera.

(4) To measure the degree of volatilization, the apparatus was covered, and air in the appara-

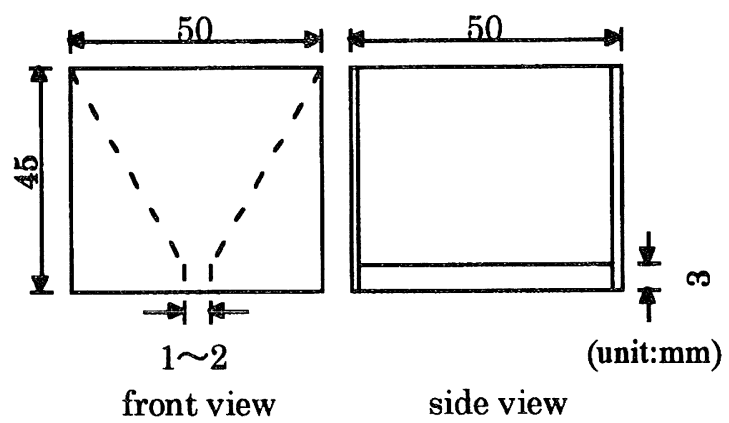

Fig. 2 Dimension of rectangle funnel for NAPL injection (method A) 
tus was drawn out at a weak flow rate and injected into two methanol traps to absorb the NAPL vapor. These traps were changed every hour for the TCA-based experiment, and every two to four hours for the toluenebased experiment. The concentration of NAPL in the methanol was determined by gas chromatography with ECD or FID, and the instantaneous volatilization rate was then calculated. The total amount of volatilized NAPL was calculated by integration of the volatilization rate over the experimental period. It was confirmed by preliminary experiments that the two methanol traps could absorb about $100 \%$ of the volatilized NAPL vapor.

(5) In the experiment that simulated fluctuations of a water table, the water table level was forced to rise or fall at the rate of 1 $\mathrm{cm} / \mathrm{h}$ over the period of 12 to 23 hours after the NAPL injection.

(6) Because the NAPL mass hardly moved about 24 hours after the injection, each experiment was continued just for 24 hours. After that, the distribution of residual NAPL and the concentrations of dissolved NAPL in the water tanks were determined.

Sampling and analytical methods are as follows. Firstly, water samples were collected from both inlet and outlet water tanks. Next, the glass beads layer was divided into cells each of $5 \mathrm{~cm}$ or $2.5 \mathrm{~cm}$ in height and $4 \mathrm{~cm}$ in width, from which we sampled 10 to $20 \mathrm{~g}$ of a mixture sample, which contained glass beads, pure NAPL, and water. For the saturated zone, after lowering the water table level by 1 to $2 \mathrm{~cm}$, the mixture samples were collected, carefully confirming that the NAPL was not moved by the procedure.

The mixture sample was then placed into a 68.4 or $43.4 \mathrm{~mL}$ brown vial, and $10-20 \mathrm{~mL}$ of n-hexane was added to it. Next, the vial was capped with a Teflon seal and agitated by hand.
After further mixing ultrasonically for $30 \mathrm{~min}$ utes, the n-hexane layer was sampled to determine the concentration of NAPL. After n-hexane was removed from the vial, the remaining mixture sample was dried. The weight of water in the mixed sample was calculated from the difference between the weight of total liquid and NAPL. The weight of water in a cell mostly ranged from 0.02 to $0.26 \mathrm{~g} / \mathrm{g}$ of beads, while that of NAPL ranged from 0.00 to $100 \mathrm{mg} / \mathrm{g}$ of beads.

Although the concentration of dissolved NAPL in the layer seemed not to be homogeneous because NAPL dissolves at the interface between the pure NAPL and water phase, the total amount of dissolution was estimated to a first approximation by multiplying the concentration of dissolved NAPL in the water tanks by the volume of water in the apparatus.

Tables 2, 3 and 4 detail the experimental conditions. In the runs for experimental condition Case A, the influence of injection methods and injection volumes on NAPL plume extension was observed under a stagnant condition. Runs 8 to 10 of Case A were conducted only in the unsaturated zone, while Runs 11 and 12 were conducted in both the saturated capillary and saturated zones. The other runs of Case A were conducted in both the unsaturated and saturated zones. Cases $\mathrm{B}$ and $\mathrm{C}$ were conducted under conditions of groundwater flow and fluctuation of water table, respectively.

\section{Results and discussions}

\subsection{Capillary pressure-saturation curve}

Firstly, the capillary pressure-saturation curve of the glass beads layer is shown in Fig. 3. In Fig. 3, the zone between the bottom of the layer and the water table is defined as a saturated zone (water saturation $S_{w}=1$ ). An apparent 'water table' occurs due to capillary forces, which we have defined as an 'apparent water ta- 
Table 2 Experimental conditions: Case A

\begin{tabular}{|c|c|c|c|c|r|}
\hline $\begin{array}{c}\text { Run } \\
\text { No. }\end{array}$ & NAPL & $\begin{array}{c}\text { injected } \\
\text { NAPL } \\
\text { volume }[\mathrm{mL}\end{array}$ & $\begin{array}{c}\text { injection } \\
\text { method }\end{array}$ & $\begin{array}{c}\text { height } \\
\text { period } \\
\text { of injection }\end{array}$ & $\begin{array}{c}\text { of water } \\
\text { table }[\mathrm{cm}]\end{array}$ \\
\hline 1 & TCA & 20 & $\mathrm{~A}$ & $3 \mathrm{~s}$ & 20.0 \\
2 & TCA & 50 & $\mathrm{~A}$ & $7 \mathrm{~s}$ & 21.7 \\
3 & TCA & 100 & $\mathrm{~A}$ & $14 \mathrm{~s}$ & 21.5 \\
4 & TCA & 51.8 & B & $50 \mathrm{~min}$ & 20.0 \\
5 & Toluene & 20 & A & $3 \mathrm{~s}$ & 20.0 \\
6 & Toluene & 50 & A & $10 \mathrm{~s}$ & 20.6 \\
7 & Toluene & 50 & B & $45 \mathrm{~min}$ & 20.2 \\
$8^{*}$ & TCA & 20 & A & $3 \mathrm{~s}$ & 0.0 \\
$9^{*}$ & TCA & 50 & A & $7 \mathrm{~s}$ & 0.0 \\
$10^{*}$ & TCA & 100 & A & $11 \mathrm{~s}$ & 0.0 \\
11 & TCA & 100 & A & $30 \mathrm{~s}$ & 45.4 \\
12 & TCA & 104 & B & $20 \mathrm{~min}$ & 45.1 \\
\hline
\end{tabular}

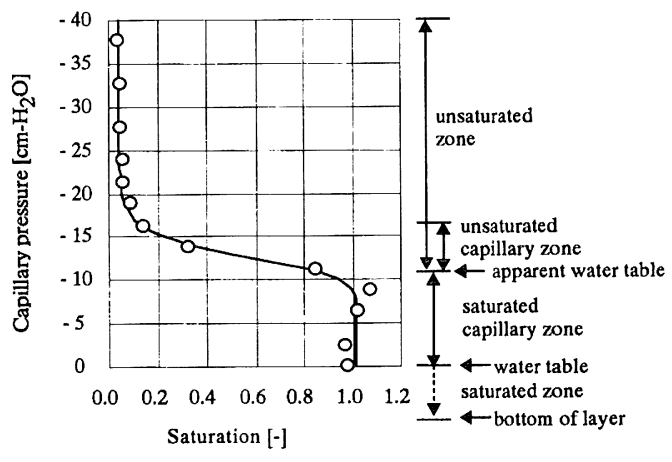

Fig. 3 Capillary pressure-Saturation Curve of grass beads layer

(Particle size: $0.5 \sim 0.7 \mathrm{~mm}$ )

Table 3 Experimental conditions: Case B

\begin{tabular}{|c|c|c|c|c|c|c|c|c|}
\hline \multirow{2}{*}{$\begin{array}{l}\text { Run } \\
\text { No. }\end{array}$} & \multirow[b]{2}{*}{ NAPL } & \multirow{2}{*}{$\begin{array}{c}\text { injected } \\
\text { NAPL } \\
\text { volume }[\mathrm{mL}]\end{array}$} & \multirow{2}{*}{$\begin{array}{c}\text { injection } \\
\text { method }\end{array}$} & \multirow{2}{*}{$\begin{array}{l}\text { period } \\
\text { of } \\
\text { injection }\end{array}$} & \multicolumn{2}{|c|}{$\begin{array}{c}\text { height of } \\
\text { water table }[\mathrm{cm}]\end{array}$} & \multirow{2}{*}{$\begin{array}{c}\text { hydraulic } \\
\text { gradient } \\
{[-]}\end{array}$} & \multirow{2}{*}{\begin{tabular}{|c} 
darcy \\
velocity \\
[m/day] \\
\end{tabular}} \\
\hline & & & & & inlet & outlet & & \\
\hline 13 & & $\overline{50}$ & 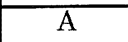 & $7 \mathrm{~s}$ & 21.0 & 20.7 & 0.007 & 2.5 \\
\hline 14 & & 20 & $t$ & $3 s$ & 22.0 & 20.5 & 0.03 & 11.0 \\
\hline 15 & TCA & 50 & A & $7 \mathrm{~s}$ & 21.8 & 19.9 & 0.04 & 12.0 \\
\hline 16 & Toluene & 50 & A & $7 \mathrm{~s}$ & 21.0 & 20.7 & 0.007 & 2.5 \\
\hline
\end{tabular}

Table 4 Experimental conditions: Case C

\begin{tabular}{|c|c|c|c|c|c|c|c|c|c|c|}
\hline \multirow{2}{*}{$\begin{array}{l}\text { Run } \\
\text { No. }\end{array}$} & \multirow[b]{2}{*}{ NAPL } & \multirow{2}{*}{$\begin{array}{c}\text { injected } \\
\text { NAPL } \\
\text { volume }[\mathrm{mL}]\end{array}$} & \multirow{2}{*}{$\begin{array}{l}\text { injection } \\
\text { method }\end{array}$} & \multirow{2}{*}{$\begin{array}{c}\text { period } \\
\text { of } \\
\text { injection }\end{array}$} & \multicolumn{2}{|c|}{$\begin{array}{l}\text { initial height of } \\
\text { water table }[\mathrm{cm}]\end{array}$} & \multirow{2}{*}{$\begin{array}{c}\text { hydraulic } \\
\text { gradient } \\
{[-]}\end{array}$} & \multirow{2}{*}{$\begin{array}{c}\text { darcy } \\
\text { velocity } \\
{[\mathrm{m} / \text { day }]}\end{array}$} & \multicolumn{2}{|c|}{$\begin{array}{c}\text { final height of } \\
\text { water table }[\mathrm{cm}]\end{array}$} \\
\hline & & & & & inlet & outlet & & & inlet & outlet \\
\hline 17 & TCA & 20 & $\bar{A}$ & $3 s$ & 20.8 & 20.3 & 0.01 & 2.8 & 11.5 & 11.0 \\
\hline 18 & $\mathrm{TCA}$ & 20 & A & $3 s$ & 20.8 & 20.5 & 0.01 & 2.7 & 30.8 & 30.4 \\
\hline 19 & Toluene & 50 & A & $7 \mathrm{~s}$ & 20.3 & 19.9 & 0.009 & 2.5 & 12.0 & 11.5 \\
\hline 20 & Toluene & 50 & A & $7 \mathrm{~s}$ & 20.2 & 19.8 & 0.009 & 2.6 & 31.5 & 31.1 \\
\hline
\end{tabular}

ble'. The zone between the water table and the apparent water table was also defined as a saturated capillary zone $\left(S_{\mathrm{w}} \fallingdotseq 1\right)$, and the zone above the apparent water table was defined as an unsaturated zone. In the unsaturated zone, in particular the zone where water saturation declines markedly is defined as an unsaturated capillary zone.

\subsection{Behavior of NAPL under the experi- mental condition Case A}

1) Unsaturated zone

As examples, some video pictures in Runs
2 and 6 are shown in Fig. 4. In addition, to observe the influence of the injection method and injected NAPL volume on plume configurations and migration rate, the coordinates of key points showing the characteristics of instantaneous NAPL plume, such as the lowest point, and the left and the right edges, were traced at some time intervals from the video pictures. Fig. 5 and 6 show downward migration and lateral spreading in the unsaturated zone for pure TCA (Runs 1 to 4), and pure toluene (Runs 5 to 7), respectively. The elapsed time of each point in the left figure, shown as a dotted line, corre- 


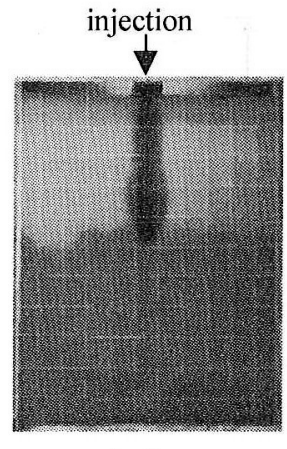

$1 \mathrm{~min}$ injection

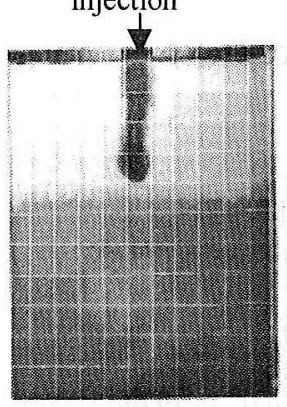

$1 \mathrm{~min}$

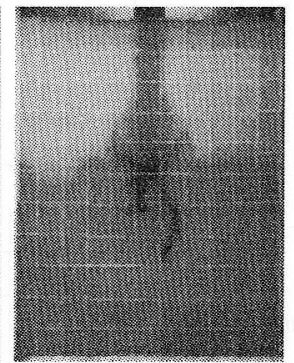

$10 \mathrm{~min}$

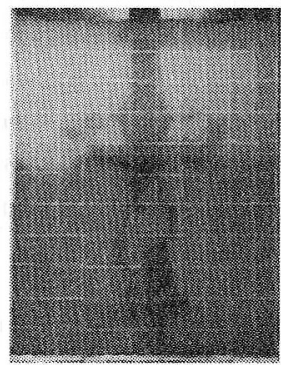

$1 \mathrm{~h}$

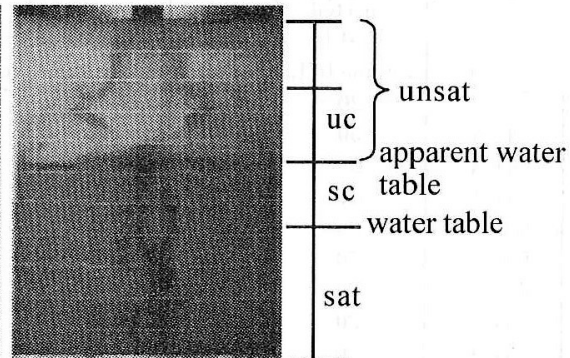

$24 \mathrm{~h}$

(a) Run 2

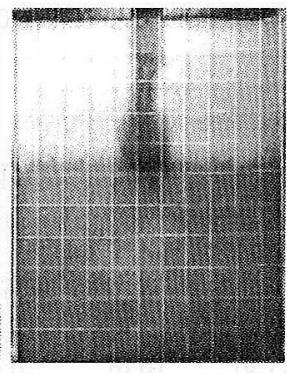

$10 \mathrm{~min}$

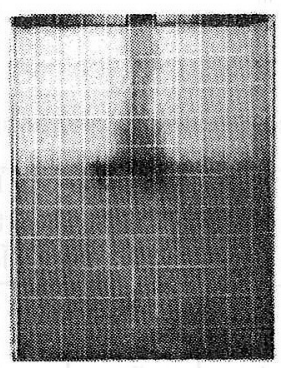

$1 \mathrm{~h}$

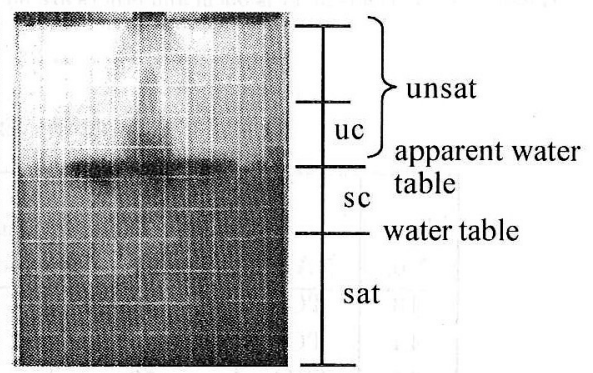

$24 \mathrm{~h}$

(b) Run 6

Fig. 4 Video pictures in Run 2 and 6 (Case A)

(a)TCA, injected TCA volume: $50 \mathrm{~mL}$, injection method $A$

(b)Toluene, injected toluene volume: $50 \mathrm{~mL}$, injection method $A$

The mesh size is $5 \mathrm{~cm}$ (height) $\times 4 \mathrm{~cm}$ (width).

unsat: unsaturated zone, uc: unsaturated capillary zone

sc: saturated capillary zone, sat: saturated zone

sponds to the elapsed time in the right figure.

Firstly, the behaviors of NAPL plumes were compared with each other under different injection rates. The pure TCA plume in Run 3 of injection method A spread laterally during the period of injection (14 s), and then migrated downward, keeping a constant width $(6.6 \mathrm{~cm})$ following the end of the injection. On the other hand, in Run 4 of injection method $B$, the width of the pure TCA plume seemed to be very small, because the plume could not be detected in the video pictures. The behavior of the pure toluene plume in Runs 5 to 7 showed the same tendency as that of the pure TCA plume. The width of the pure toluene plume was also deter- mined at the end of its injection and was changed little during its downward migration.

Next, in order to observe the pure TCA plume spreading in the unsaturated zone in more detail, the depth of the unsaturated zone in Runs 8 to 10 was extended to about $40 \mathrm{~cm}$. The widths of the plume at the ends of the injection were $3 \mathrm{~cm}$ (Run 8), $4 \mathrm{~cm}$ (Run 9), and $6.7 \mathrm{~cm}$ (Run 10), respectively (not shown in figures), and were constant during the downward migration. Therefore, it was found that the width of the plume in the unsaturated zone depends on the injection rate and the period of injection. This experimental study provided quantitative data to evaluate available mathematical 
models with respect to the influence of the injection rate and the period of injection.

With respect to the difference in NAPL characteristics, the pure toluene plume migrated downward at a slower rate than the pure TCA plume because of the higher kinematic viscosity of toluene. In comparison to Runs 2 (Fig. 5) and 6 (Fig. 6) using the same injection method,

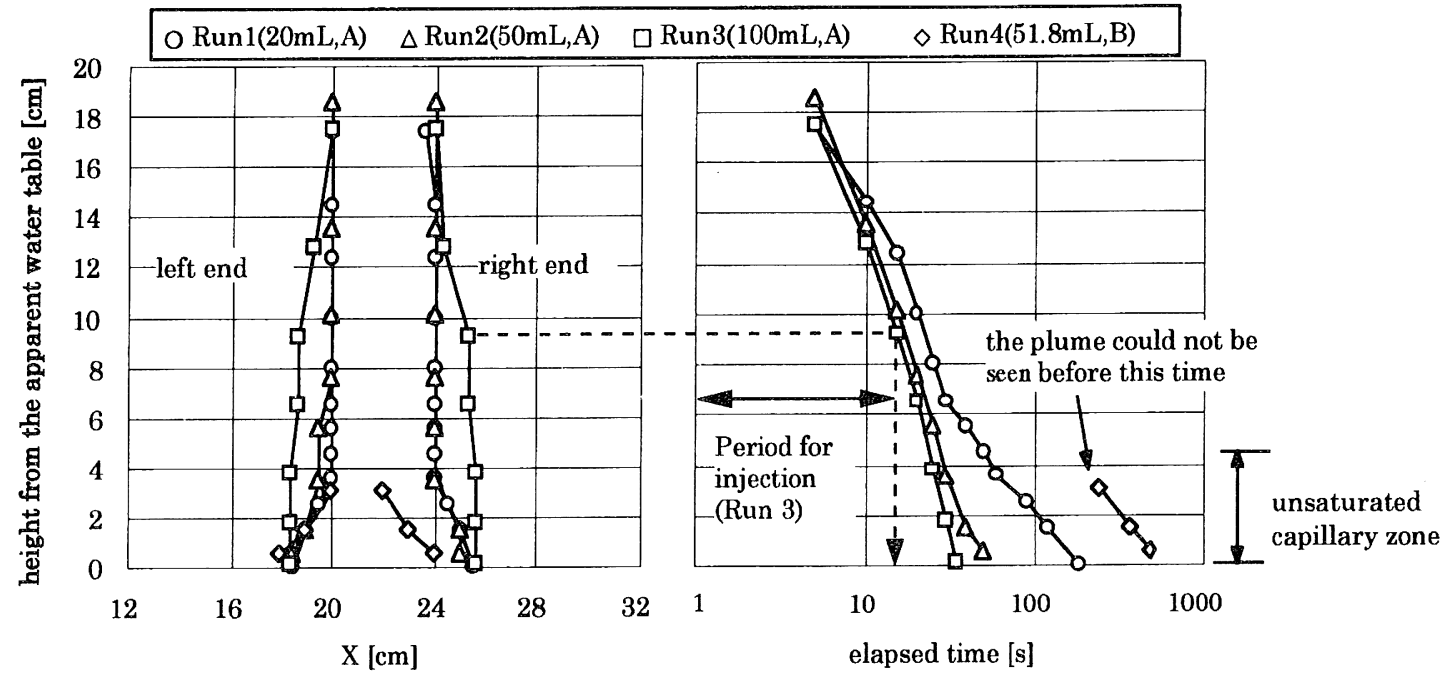

(a) locuses of $\mathrm{Y}$ vs $\mathrm{X}$ positions of instantaneous left and right ends of pure TCA migration plume at some intervals of time

(b) instantaneous lowest vertical position of pure TCA migration plume vs time

Fig. 5 The downward migration and lateral spreading of pure TCA in the unsaturated zone from Run 1 to Run 4

O Run $5(20 \mathrm{~mL}, \mathrm{~A}) \quad \Delta$ Run $6(50 \mathrm{~mL}, \mathrm{~A}) \quad \square \operatorname{Run} 7(50 \mathrm{~mL}, \mathrm{~B})$

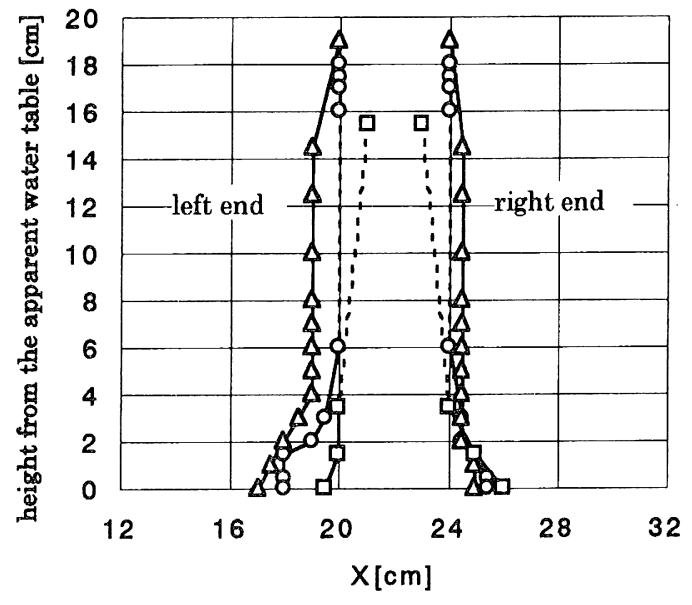

(a) locuses of $Y$ vs $X$ positions of instantaneous left and right ends of pure toluene migration plume at some intervals of time

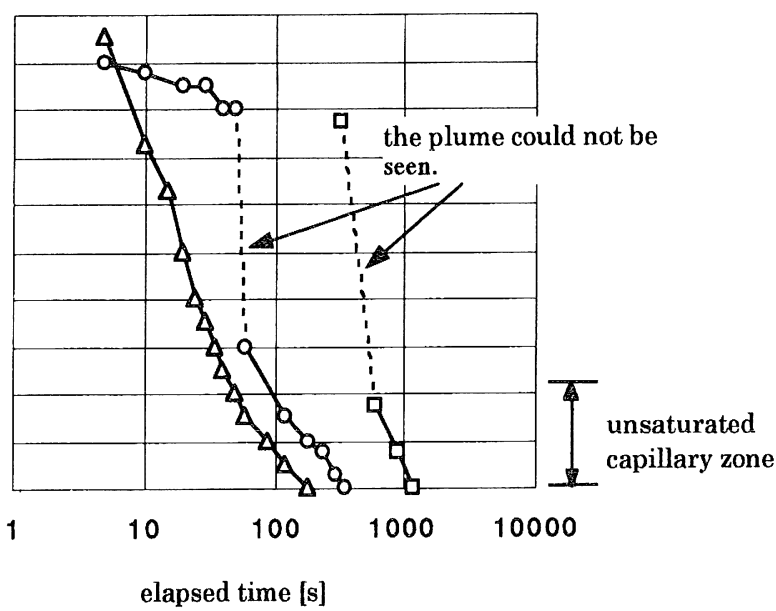

(b) instantaneous lowest vertical position of pure toluene migration plume vs time

Fig. 6 The downward migration and lateral spreading of pure toluene in the unsaturated zone from Run 5 to Run 7 
the width of the pure toluene plume seemed to be a little larger than that of the pure TCA plume because of the lower downward migration rate. In a previous study, Schwille (1988) observed that pure PCE migrated downward at a faster rate than pure dichloromethane (DCM), although the kinematic viscosity of pure PCE (v $\left.=0.54 \mathrm{~mm}^{2} / \mathrm{s}\right)$ is larger than that of pure DCM $\left(v=0.32 \mathrm{~mm}^{2} / \mathrm{s}\right)$. Moreover, the width of the pure PCE plume was significantly narrower than that of pure DCM. Ishii et al. (1998) also reported that pure bromoform migrated downward faster than other NAPLs (pure TCE, TCA, or toluene), although the kinematic viscosity of pure bromoform $\left(v=0.727 \mathrm{~mm}^{2} / \mathrm{s}\right)$ is the highest among these NAPLs. Since the spread coefficient $\left(=\sigma_{\mathrm{aw}}-\sigma_{\mathrm{an}}-\sigma_{\mathrm{nw}} ; \sigma_{\mathrm{ij}}\right.$ : surface tension between $i$ and $j$ phase; a: air, n: NAPL, and w: water) of both pure PCE and bromoform is negative value, neither fluid tends to spread on particles covered with water (Adamson, 1990). While fluids that have a positive spread coefficient value tend to spread over them (Adamson, 1990). From this fact, it is clear that plumes of pure PCE and bromoform hardly spread laterally in the unsaturated zone because capillary forces are not at work. Therefore, the higher downward migration rate of pure PCE and bromoform can be explained by their negative spread coefficients. Hofstee et al. (1997) measured the capillary pressure-saturation curve of pure PCE and concluded that the Leverett function (Leverett, 1941) was valid over only a limited range of saturation. This indicated that the capillary behavior of pure PCE was different from other NAPLs that have positive spread coefficients. Consequently, based on the present and previous studies, it is suggested that the downward migration rates in an unsaturated zone does not follow the order of kinematic viscosities for NAPLs that have negative spread coefficients.

2) Saturated and unsaturated capillary zones, and the saturated zone

When both pure TCA and toluene reached the unsaturated capillary zone, their plumes spread laterally to both the right and left sides to form a bell shape. In addition, when they reached the apparent water table, they spread further laterally. Pure toluene then floated above the water table, while pure TCA penetrated the water table and migrated further downward into the saturated zone. However, pure TCA, which is a DNAPL, stagnated above the water table. Table 5 shows the mass balance for TCA and toluene in Runs $1,2,4,5,6$, and 7 , their vertical distribution in the glass beads layer and their degrees of volatilization and dissolution. It

Table 5 Residual NAPL distribution and the amount of dissolved and volatilized NAPL (Case A)

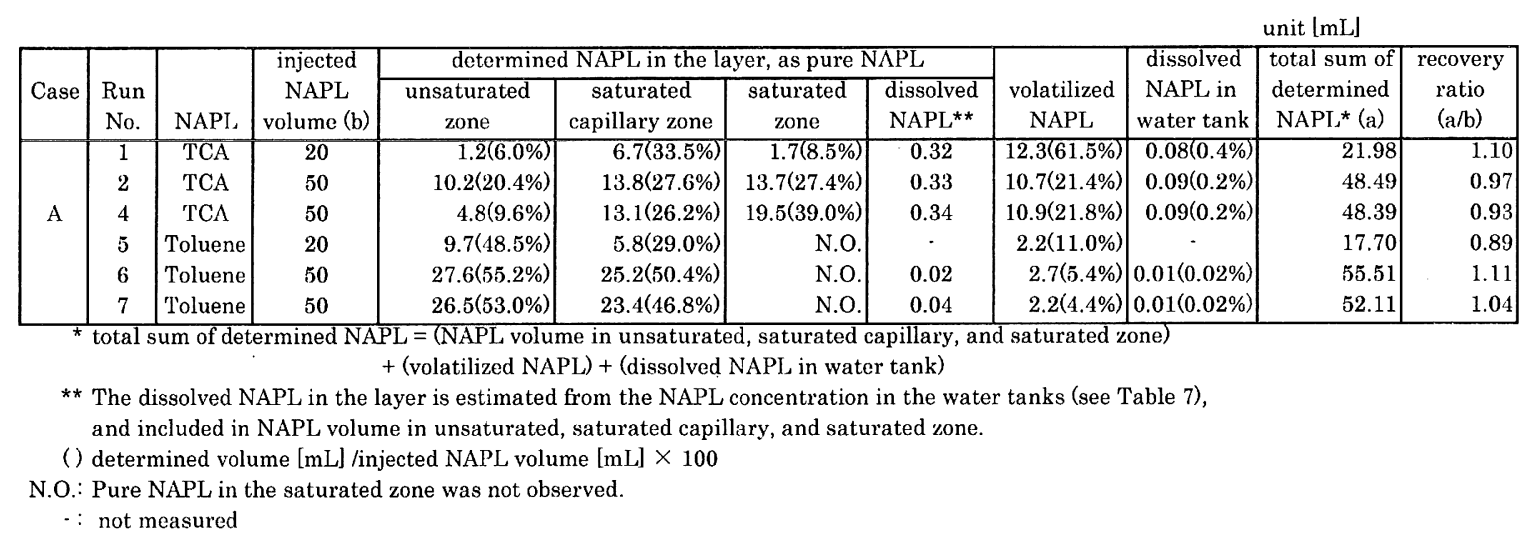


was found that 36 to $48 \%$ of the injected pure TCA volume stagnated in the unsaturated zone and the saturated capillary zone. Only about 10 $\%$ of the injected pure TCA stagnated above the water table in a previous one-dimensional experiment conducted by Ishii et al. (1998). The reason why a larger amount of pure TCA stagnated in this two-dimensional experiment could be that the pure TCA pressure on the water table was dispersed and reduced.

Fig. 7 shows the extent of lateral spreading in the vicinity of the apparent water table ( \pm $2.5 \mathrm{~cm}$ above and below the apparent water table). The extent of the spreading of pure TCA seemed to be larger than that of pure toluene. According to the two-dimensional distribution of pure TCA (Run 2) and pure toluene (Run 6) as shown in Fig. 8, however, pure TCA did not spread significantly less than pure toluene. In the experiments with TCA, some $64 \%$ to 97 $\%$ of the pure TCA, lying in the saturated capil-

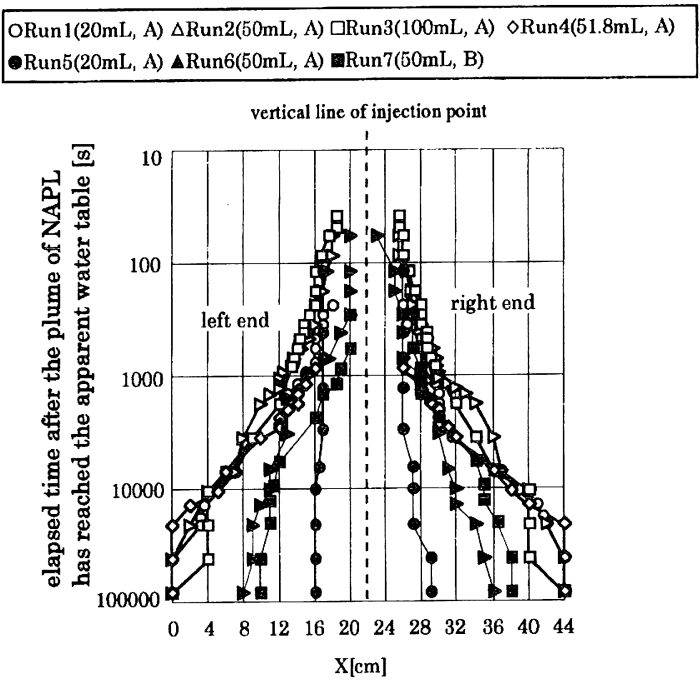

Fig. 7 The extint of pure TCA $(\bigcirc \Delta \square \diamond)$ and pure toluene ( $\triangle \mathbf{A}$ ) lateral spread in the vicinity of the apparent water table $( \pm 2.5$ $\mathrm{cm}$ from the apparent water table) from Run 1 to Run 7
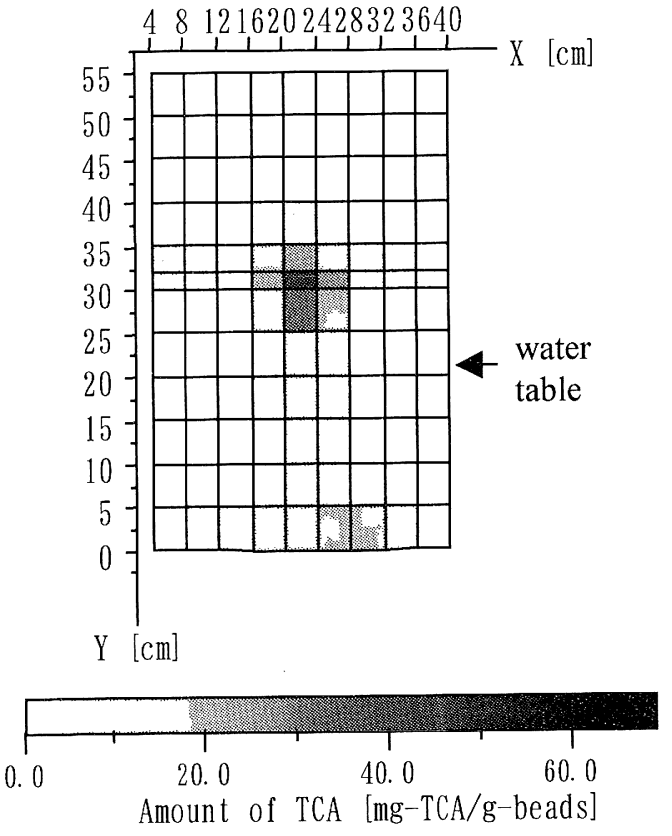

(a) TCA (Run2)
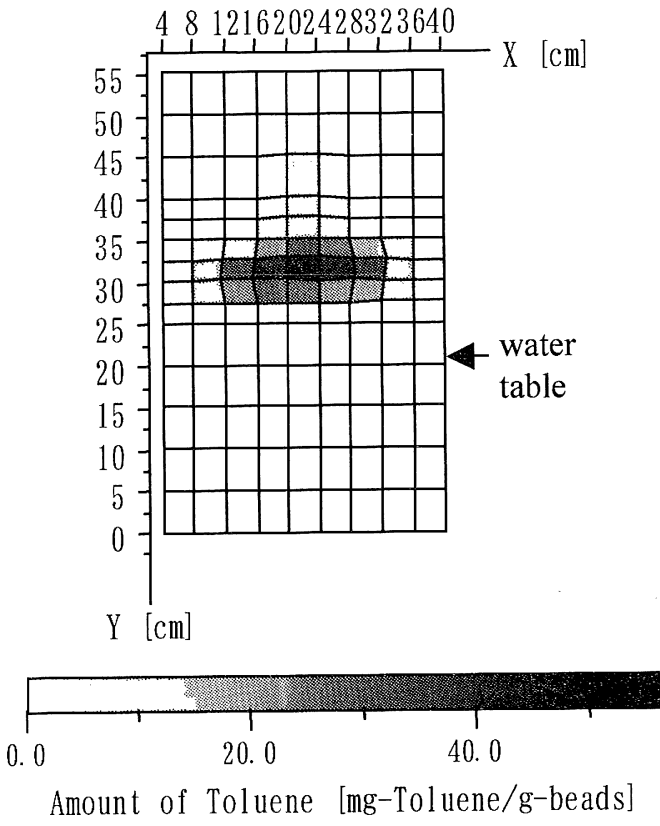

(b) Toluene (Run6)

Fig. 8 Two-dimensional distribution of pure TCA and toluene in the glass beads layer 
lary and unsaturated capillary zones, remained within $2 \mathrm{~cm}$ of the left and right sides of the vertical line of injection. Therefore, it was found that the degree of pure TCA spreading in these zones could be considered negligible.

In addition, as shown in Fig. 7, the lateral spreading of pure TCA did not depend on either the injection method or the injected volume, while that of pure toluene depended on only the injected volume. This is because pure toluene is lighter than water and most of the pure toluene stagnated on the water table. We cannot discuss the case of TCA in detail because the degree of lateral spreading of the pure TCA was very small. However, it was observed during sampling and from the video pictures that pure TCA spread just above the apparent water table, while pure toluene spread in the saturated capillary zone (just below the apparent water table). Therefore, pure TCA may spread laterally without displacing the water in pores. Apparently, that is why the lateral spreading of pure TCA was independent of the injection method and the injected volume.

In the saturated zone, the degree of lateral spreading of pure TCA was small in Runs 1 to 4, and 11 and 12 (not shown in the figures). Toluene, which is lighter than water, did not migrate into the saturated zone.

\subsection{Behavior of NAPL under the experi- mental conditions Case B}

Two examples of the video pictures of Runs 15 and 16 under Case B, in which groundwater flow was simulated, are shown in Fig. 9. The mass balances for NAPL are also shown in Table 6 . The pure TCA plume was hardly affected by groundwater flow at a rate of about 12 $\mathrm{m} /$ day (the hydraulic gradient, $\mathrm{i}=0.04$ ), and this was larger than the rate reported by Schwille (1988). On the other hand, the pure toluene plume was transported downgradient by a groundwater flow of $2.5 \mathrm{~m} /$ day $(i=0.007)$.

Larson et al. (1981) obtained relationships between residual oil saturation and capillary number $\left(C a=\mu_{\mathrm{w}} \mathrm{V} / \sigma_{\text {ow }} ; \mu_{\mathrm{w}}\right.$ : viscosity of water phase; V: Darcy velocity), which determines the relative importance of viscous and capillary forces on two-phase flow, from a considerable amount of experimental data, and reported that disconnected NAPL trapped in pores begins to move under the condition of $\mathrm{Ca}>10^{-4}$, while connected NAPL in pores begins to move under the condition of $C a>10^{-6}$ to $10^{-5}$. In the present study, the values of $\mathrm{Ca}$ in Runs 15 and 16 were $2.5 \times 10^{-6}$ and $6.3 \times 10^{-7}$, respectively. Therefore, it was inferred that pure TCA must be disconnected in Run 15 because if it had been connected, it might have been transported by groundwater flow. On the other hand, it was assumed, for the same reason, to be difficult for pure toluene to be transported under the experimental condition of Run 16, however pure toluene was in fact apparently transported. This suggests pure toluene would not be transported by the groundwater flow, but moved laterally along the hydraulic gradient due to its pressure head.

\subsection{Behavior of NAPL under the experi- mental conditions Case C}

Examples of the video pictures obtained from the experiment of Case $\mathrm{C}$ are shown in Fig. 10. When the water table fell, both NAPLs migrated downward, as observed in previous studies (Schwille, 1988; Yagi, 1996). However, pure toluene was transported further laterally from the vertical line of injection point (see Run 19). This suggested that even if migration of pure toluene stopped at the water table, it could still be transported downgradient again because of water table fluctuations.

On the other hand, when the water table rose, pure TCA was not transported upwards because all pure TCA had already been trapped as disconnected TCA in pores, while some part of 


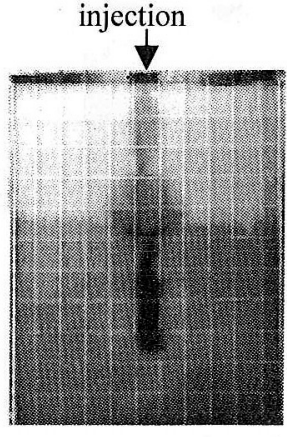

$10 \mathrm{~min}$

injection

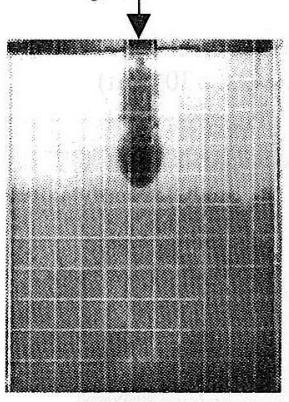

$1 \mathrm{~min}$

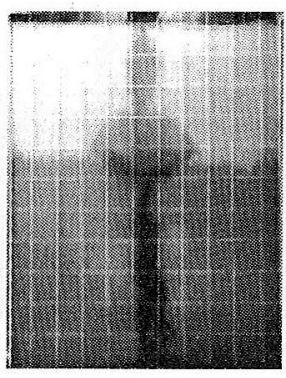

$20 \mathrm{~min}$

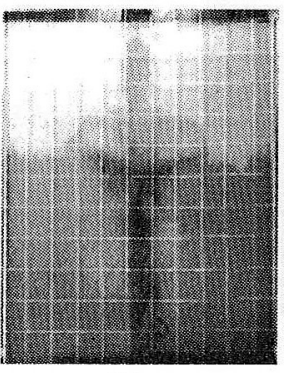

$1 \mathrm{~h}$

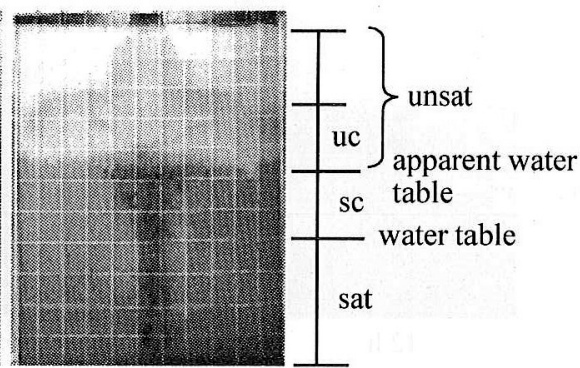

$24 \mathrm{~h}$

(a)Run 15

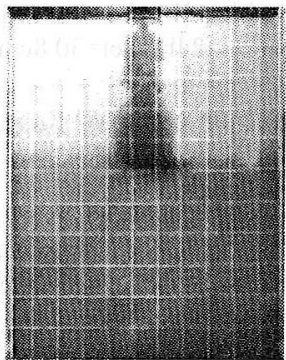

$10 \mathrm{~min}$

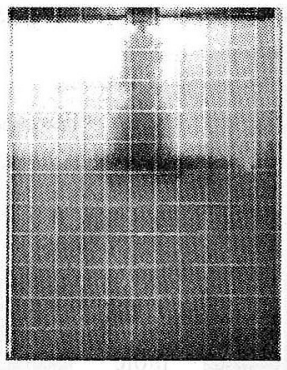

$1 \mathrm{~h}$

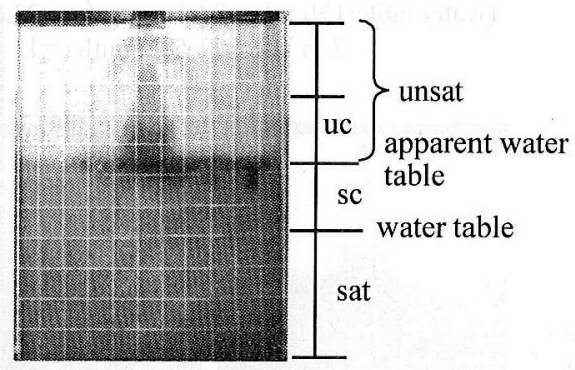

$24 \mathrm{~h}$

(b)Run 16

Fig. 9 Video pictures in Run 15 and 16 (Case B)

(a)TCA, injected TCA volume: $50 \mathrm{~mL}$, injection method $A$, darcy velocity: $12.0 \mathrm{~m} /$ day (b)Toluene, injected toluene volume: $50 \mathrm{~mL}$, injection method A,darcy velocity: $2.5 \mathrm{~m} /$ day The mesh size is $5 \mathrm{~cm}$ (height) $\times 4 \mathrm{~cm}$ (width).

unsat: unsaturated zone, uc: unsaturated capillary zone

sc: saturated capillary zone, sat: saturated zone

Table 6 Residual NAPL distribution and the amount of dissolved and volatilized NAPL (Case B and C)

\begin{tabular}{|c|c|c|c|c|c|c|c|c|c|c|c|}
\hline \multirow[b]{2}{*}{ Case } & \multirow[b]{2}{*}{$\begin{array}{l}\text { Run } \\
\text { No. }\end{array}$} & \multirow[b]{2}{*}{ NAPL } & \multirow{2}{*}{$\begin{array}{l}\text { injected } \\
\text { NAPL } \\
\text { volume (b) }\end{array}$} & \multicolumn{4}{|c|}{ determined NAPL in the layer, as pure NAPL } & \multirow[b]{2}{*}{$\begin{array}{l}\text { volatilized } \\
\text { NAPL }\end{array}$} & \multirow{2}{*}{$\begin{array}{c}\text { dissolved } \\
\text { NAPL in } \\
\text { water tank }\end{array}$} & \multirow{2}{*}{$\begin{array}{l}\text { total sum of } \\
\text { determined } \\
\text { NAPL }^{*}(a)\end{array}$} & \multirow{2}{*}{$\begin{array}{c}\text { recovery } \\
\text { ratio } \\
(a / b)\end{array}$} \\
\hline & & & & $\begin{array}{l}\text { unsaturated } \\
\text { zone }\end{array}$ & $\begin{array}{c}\text { saturated } \\
\text { capillary zone }\end{array}$ & $\begin{array}{l}\text { saturated } \\
\text { zone }\end{array}$ & $\begin{array}{l}\text { dissolved } \\
\text { NAPL** }\end{array}$ & & & & \\
\hline \multirow{4}{*}{ B } & $\overline{13}$ & TCA & 50 & $5.7(11.4 \%)$ & $9.4(18.8 \%)$ & $9.3(18.6 \%)$ & 1.89 & $12.2(24.4 \%)$ & $0.51(1.0 \%)$ & 37.11 & 0.74 \\
\hline & 14 & $\mathrm{TCA}$ & 20 & $1.9(9.5 \%)$ & $1.2(6.0 \%)$ & $2.6(13.0 \%)$ & 1.42 & $15.2(76.0 \%)$ & $0.38(1.9 \%)$ & 21.28 & 1.06 \\
\hline & 15 & TCA & 50 & $9.3(18.6 \%)$ & $7.9(15.8 \%)$ & $6.7(13.4 \%)$ & - & $11.8(23.6 \%)$ & - & 35.70 & 0.71 \\
\hline & 16 & Toluene & 50 & $29.4(58.8 \%)$ & $17.7(35.4 \%)$ & N.O. & 0.28 & $2.7(5.4 \%)$ & $0.07(0.1 \%)$ & 49.87 & 1.00 \\
\hline \multirow{4}{*}{$\mathrm{C}$} & 17 & TCA & 20 & $0.42(2.1 \%)$ & $4.5(22.5 \%)$ & N.O. & 0.65 & $9.0(45.0 \%)$ & $0.1(0.5 \%)$ & 14.02 & $\overline{0.70}$ \\
\hline & 18 & TCA & 20 & 0.0 & $5.2(26.0 \%)$ & $2.9(14.5 \%)$ & 1.75 & $11.3(56.5 \%)$ & $0.5(2.5 \%)$ & 19.90 & 1.00 \\
\hline & 19 & Toluene & 50 & $23.8(47.6 \%)$ & $28.3(56.6 \%)$ & N.O. & 0.78 & $2.7(5.4 \%)$ & $0.05(0.1 \%)$ & 54.85 & 1.10 \\
\hline & 20 & Toluene & 50 & $10.5(21.0 \%)$ & $30.1(60.2 \%)$ & N.O. & 0.92 & $2.6(5.2 \%)$ & $0.1(0.2 \%)$ & 43.30 & 0.87 \\
\hline
\end{tabular}

$$
+ \text { (volatilized NAPL) + (dissolved NAPL in water tank) }
$$

** The dissolved NAPL in the layer is estimated from the NAPL concentration in the water tanks (see Table 7), and included in NAPL volume in unsaturated, saturated capillary, and saturated zone.

() determined volume $[\mathrm{mL}] /$ injected NAPL volume $[\mathrm{mL}] \times 100$

N.O.: Pure NAPL in the saturated zone was not observed.

$\because$ not measured 


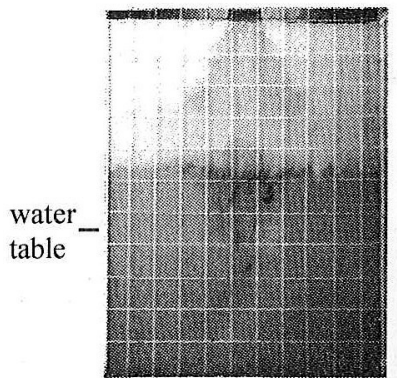

$12 \mathrm{~h}$

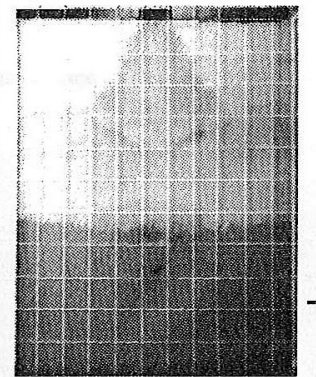

$24 \mathrm{~h}$

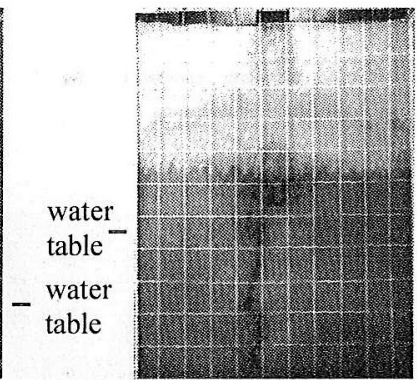

$12 \mathrm{~h}$

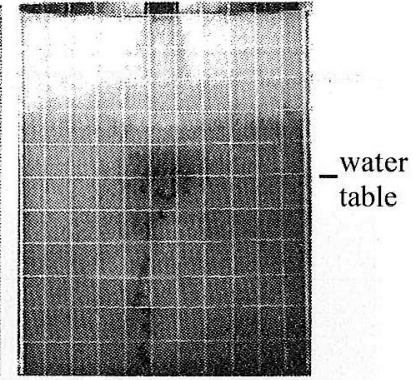

$24 \mathrm{~h}$

(a)Run 17 (TCA) injected TCA volume : $20 \mathrm{~mL}$ injection method $\mathrm{A}$ (water table: $12 \mathrm{~h}$ inlet $=22.4 \mathrm{~cm}$, outlet $=22.0 \mathrm{~cm}$ $24 \mathrm{~h}$ inlet $=11.5 \mathrm{~cm}$, outlet $=11.0 \mathrm{~cm}$ )

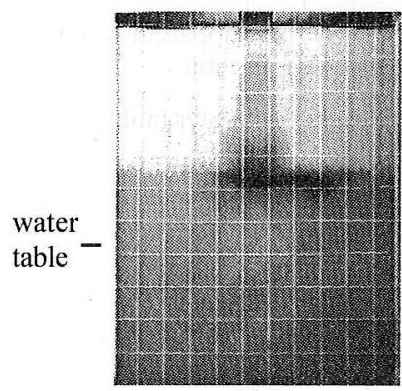

$12 \mathrm{~h}$

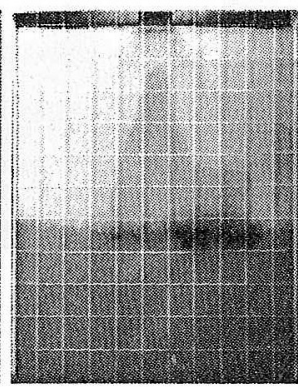

$24 \mathrm{~h}$

(c)Run 19 (toluene)

injected toluene volume : $50 \mathrm{~mL}$ injection method $\mathrm{A}$

( water table: $12 \mathrm{~h}$ inlet $=22.3 \mathrm{~cm}$, outlet $=21.9 \mathrm{~cm}$ $24 \mathrm{~h}$ inlet $=12.0 \mathrm{~cm}$, outlet $=11.5 \mathrm{~cm}$ )

(b)Run 18 (TCA)

injected TCA volume : $20 \mathrm{~mL}$

injection method $\mathrm{A}$

(water table: $12 \mathrm{~h}$ inlet $=22.6 \mathrm{~cm}$, outlet $=22.2 \mathrm{~cm}$ $24 \mathrm{~h}$ inlet $=30.8 \mathrm{~cm}$, outlet $=30.4 \mathrm{~cm}$ )

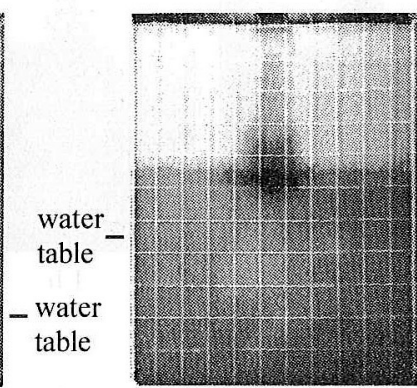

$12 \mathrm{~h}$

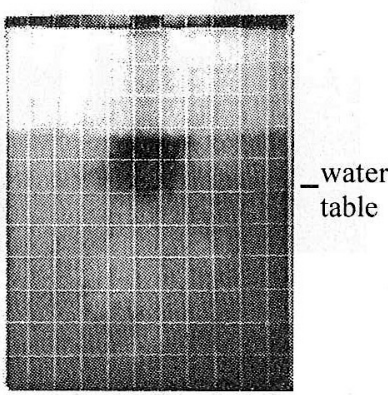

$24 \mathrm{~h}$
(d)Run 20 (toluene)

injected toluene volume : $50 \mathrm{~mL}$

injection method $\mathrm{A}$

( water table: $12 \mathrm{~h}$ inlet $=22.3 \mathrm{~cm}$, outlet $=21.9 \mathrm{~cm}$ $24 \mathrm{~h}$ inlet $=31.5 \mathrm{~cm}$, outlet $=31.1 \mathrm{~cm}$ )

Fig. 10 Video pictures from Run 17 to Run 20 (Case C)

the pure toluene was transported upward and the other part was trapped (see Run 20). In Run 20, the capillary number during water table rising was calculated to be $3.7 \times 10^{-4}$. Larson et al. (1981) reported that about half the amount of NAPL in a maximum residual saturation could be transported and the other half could be trapped under conditions with the same capillary number. We infer that is why all of the toluene was not transported upwards.

\subsection{NAPL mass balance}

The volatilization rates in Runs $1,2,5,15$, and 16 are shown in Fig. 11. The rate for TCA was larger than that for toluene, because the vapor pressure of TCA is larger than that of toluene. The peak rate for both NAPLs appeared about four or five hours after the NAPL injection, and then decreased gradually. As shown in Tables 5 and 6 , in the case where $50 \mathrm{~mL}$ of NAPLs was injected, $21 \%$ to $24 \%$ of the TCA and about $5 \%$ of the toluene was volatilized.

The concentrations of dissolved NAPLs in the water tanks are shown in Table 7 . Under the conditions of Case A, the concentrations, which are the averages in the inlet and outlet water tanks, were much less than their solubilities (see Table 1). On the other hand, under the con- 


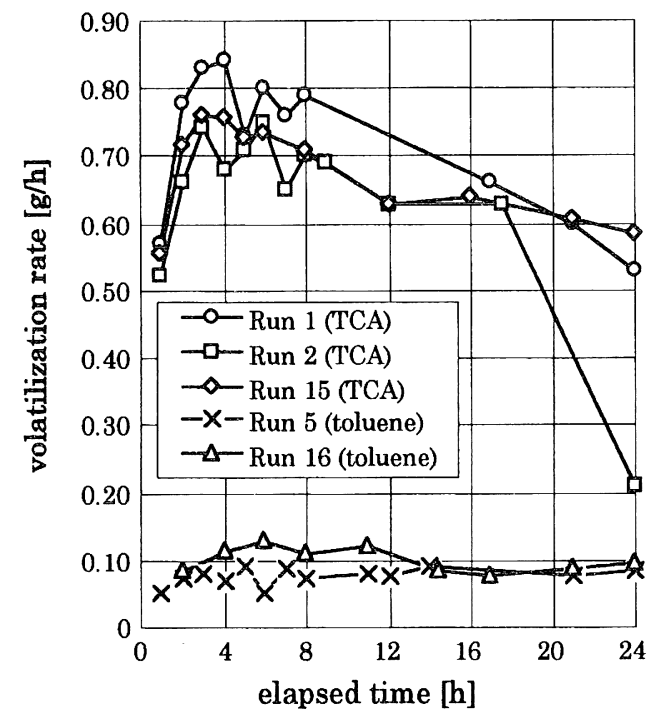

Fig. 11 The volatilization rate

Each marker is an average rate for 1 hour in TCA, and for 2 to 4 hours in toluene.

ditions of Cases $\mathrm{B}$ and $\mathrm{C}$, the concentration for dissolved toluene in the outlet water tank was about one order of magnitude higher than that in the inlet. The concentrations of dissolved TCA in both water tanks were almost the same, and near to its solubility. Because recycling water simulated groundwater flow, the ideal condition of supplying uncontaminated water from the inlet side could not be achieved in these experiments.

In tables 5 and 6 , total recovery ratios for Runs 13, 15, and 17 were very low because pure TCA on the bottom of the glass beads layer could not be collected completely in Runs 13 and 15, and the degree of volatilization in Run 17 was much smaller than that in all other experiments. The recovery ratios of all other runs were about $100 \%$ within an error of about $10 \%$ due to the sampling losses of NAPL during collection of the mixture samples and analytical errors in the determinations of NAPL concentrations in $\mathrm{n}$-hexane.
Table 7 The concentration of dissolved NAPLs in water tanks

\begin{tabular}{|c|c|c|c|c|}
\hline \multirow[b]{2}{*}{ case } & \multirow[b]{2}{*}{ Run } & \multirow[b]{2}{*}{ NAPL } & \multicolumn{2}{|c|}{ Concentration $[\mathrm{mg} / \mathrm{L}]$} \\
\hline & & & inlet & outlet \\
\hline \multirow{6}{*}{ A } & 1 & $\overline{\mathrm{TCA}}$ & \multicolumn{2}{|c|}{169} \\
\hline & 2 & $\overline{\mathrm{TCA}}$ & \multicolumn{2}{|c|}{179} \\
\hline & 4 & TCA & \multicolumn{2}{|c|}{184} \\
\hline & 5 & toluene & \multicolumn{2}{|c|}{-} \\
\hline & 6 & toluene & \multicolumn{2}{|c|}{7.0} \\
\hline & 7 & toluene & \multicolumn{2}{|c|}{12.5} \\
\hline \multirow{4}{*}{ B } & 13 & $\overline{\mathrm{TCA}}$ & \multicolumn{2}{|c|}{1000} \\
\hline & $\overline{14}$ & TCA & \multicolumn{2}{|c|}{750} \\
\hline & 15 & TCA & \multicolumn{2}{|c|}{-} \\
\hline & 16 & toluene & 18 & 170 \\
\hline \multirow{4}{*}{$\mathrm{C}$} & 17 & TCA & \multicolumn{2}{|c|}{460} \\
\hline & 18 & TCA & \multicolumn{2}{|c|}{780} \\
\hline & $\overline{19}$ & toluene & $\overline{32}$ & 230 \\
\hline & 20 & toluene & 39 & 147 \\
\hline
\end{tabular}

- : not measured

\section{Conclusion}

In this study, the two-dimensional behavior of pure TCA and toluene in layers of glass beads was observed, considering a total mass balance through determination of the two-dimensional distribution of residual NAPL and the degrees of volatilization and dissolution. The following main results were obtained.

1 ) In the case where $50 \mathrm{~mL}$ of pure TCA was injected, about $21 \%$ to $24 \%$ of TCA volatilized, 0.4 to $2 \%$ dissolved, and about 75 $\%$ remained as pure liquid in the glass beads layer. The amount of TCA remaining above the water table (in both the unsaturated zone and saturated capillary zone) reached to 30 to $48 \%$. On the other hand, when $50 \mathrm{~mL}$ of pure toluene was injected, about $5 \%$ of the toluene volatilized, 0.02 to $0.2 \%$ dissolved, and about $95 \%$ remained as a pure liquid in the glass beads layer.

2 ) For the some patterns of injection rates and 
periods of injection, the width of the plumes migrating downward in the unsaturated zone tended to be constant. In addition, it was found that the downward migration rate in an unsaturated zone does not follow the order of kinematic viscosities in the case of NAPLs that have a negative spread coefficient value.

3 ) The extent of lateral spreading of pure TCA in the vicinity $( \pm 2.5 \mathrm{~cm})$ of an apparent water table appeared to be larger than that of pure toluene. However, quantitatively pure TCA spread laterally less than pure toluene, and 64 to $97 \%$ of the pure TCA in the saturated capillary and unsaturated capillary zones remained within $2 \mathrm{~cm}$ of a vertical injection line. This suggests that lateral spreading of pure TCA above the water table might be negligible. In addition, it was indicated that pure TCA might spread laterally without displacing the water in pores.

4 ) With respect to the effects of groundwater flow and water table fluctuations, it was observed that when the water table fell, pure toluene was transported again even if it had previously stopped above the water table. This suggests that regions that are highly saturated with pure toluene could be transported downjgradient by water table fluctuations.

\section{References}

Abriola, L.M., and Pinder, G.F. (1985a); A Multiphase Approach to the Modeling of Porous Media Contamination by Organic Compounds 1. Equation Development, Wat. Resour. Res., 21(1), 11 18

Abriola, L.M., and Pinder, G.F. (1985b); A Multiphase Approach to the Modeling of Porous Media Contamination by Organic Compounds 2. Numerical Simulation, Wat. Resour. Res., 21(1), 19 26

Adamson, W. (1990); Physical Chemistry of Surfaces
Fifth Edition, John Wiley \& Sons, Inc., 106 116

Adenekan A.E. and Patzek, T.W. (1993); Modeling of Multiphase Transport of Multicomponent Organic Contaminants and Heat in the Subsurface: Numerical Model Formulation, Wat. Resour. Res., 29(11), 3727 3740

Cary, J.W., McBride, J.F. and Simmons, C.S (1989); Observations of Water and Oil Infiltration into Soil: Some Simulation Challenges, Wat. Resour. Res., 25 (1), $73 \sim 80$

Cheng, P. and Wang, C.Y. (1996); A Multiphase Mixture Model for Multiphase, Multicomponent Transport in Capillary Porous Media 2. Numerical Simulation of the Transport of Organic Compounds in the Subsurface, Int. J. Heat Mass Transfer., 39(17), 3619 3632

Eckberg, D.K and Sunada, D.K. (1984), Nonsteady. Three-Phase Immiscible Fluid Distribution in Porous Media, Wat. Resour. Res., 20(12), 1891 1897

Falta, R.W., Javandel I., Pruess, K. and Witherspoon, P.A. (1989); Density-Driven Flow of Gas in the Unsaturated Zone due to the Evaporation of Volatile Organic Compounds, Wat. Resour. Res., 25(10), 2159 2169

Faust C.R., Guswa, J.H. and Mercer, J.W. (1989); Simulation of Three-Dimensional Flow of Immiscible Fluids within and below the Unsaturated Zone, Wat. Resour. Res., 25,(1), 2449 2464

Faust, C.R. (1985); Transport of Immiscible Fluids within and below the Unsaturated Zone: A Numerical Model, Wat. Resour. Res., 21(4), 587 596

Feenstra, S. and Cherry, J.A. (1988); Subsurface Contamination by Dense Non-aqueous Phase Liquids (DNAPL) Chemicals. Presented at Int. Groundwater Symp., Int. Assoc. Hydrogeol., Halifax, N.S., May 1 $\sim 4$

Hirata, T. and Muraoka, K. (1988); Vertical Migration of Chlorinated Organic Compounds in Porous Media, Wat. Res., 22(4), 481 484

Hofstee, C., Dane, J.H. and Hill, W.E. (1997); Threefluid Retention in Porous Media Involving Water, PCE, and Air, J. Contam. Hydrol., 25, 235 247

Host-Madsen, J. and Hogh-Jensen, K. (1992); Labora- 
tory and Numerical Investigations of Immiscible Multiphase Flow in Soil, J. Hydrol., 135, 13 52

Hunt, J.R., Sitar, N. and Udell, K.S. (1988); Nonaqeuous Phase Liquid Transport and Cleanup 1. Analysis of Mechanisms, Wat. Resour. Res., 24(8), 1247 1258 Illangasekare, T.H., Ramsey, J.L. Jr., Jensen, K.H. and Butts, M.B. (1995a), Experimental Study of Movement and Distribution of Dense Organic Contaminants in Heterogeneous Aquifers, J. Contam. Hydrol., 16, 109 130

Illangasekare, T.H. and Yates, D.N. (1995b); Nonaqueous-phase Fluids in Heterogeneous Aquifers Experimental Study, J. Environ. Eng., 121(8), 571 579

Imhoff, P.T., Jaffe, P.R. and Pinder, G.F. (1993); An Experimental Study of Complete Dissolution of a Nonaqueous Phase Liquid in Saturated Porous Media, Wat. Resour. Res., 30(2), 307 320

Ishii, K., Furuichi, T. and Tanaka, N. (1998): The Experimental Study on the Vertical Migration of Various Non-aqueous Phase Liquid, Journal of Groundwater Hydrology, 40(2), 105 120 (in Japanese)

Ishii, K., Tanaka, N., Matsuto, T. and Tojo, Y. (1995); The Behavior of Pure Trichloroethylene Liquid in Water Unsaturated/Saturated Porous Media: An Experimental Study, Proc. of Environmental Engineering Research, 32, 387 396 (in Japanese)

Kaluarachchi J.J. and Parker, J.C. (1992); Multiphase Flow with a Simplified Model for Oil Entrapment, Transport in Porous Media, 7, 1 14

Kia, S.F. (1991); Subsurface Multiphase Flow of Organic Contaminants: Model Development and Validation, Wat. Res., 25(10), 1225 1236

Kueper, B.H., Frind, E.O. (1991a); Two-Phase Flow in Heterogeneous Porous Media 1. Model Development, Wat. Resour. Res., 27(6), 1049 1057

Kueper, B.H., Frind, E.O. (1991b): Two-Phase Flow in Heterogeneous Porous Media 2. Model Application, Wat. Resour. Res., 27(6), 1059 1070

Kueper, B.H., Abbott, W. and Farquhar, G. (1989); Experimental Observation of Multiphase Flow in Heterogeneous Porous Media, J. Contam. Hydrol., 5, 83 95
Kuppusamy, T.,Sheng, J., Parker, J.C. and Lenhard, R.J. (1987); Finite-Element Analysis of Multiphase Immiscible Flow through Soils, Wat. Resour. Res., 23(4), 625 631

Larson, R.G., Davis, H.T. and Scriven L.E. (1981); Displacement of Residual Nonwetting Fluid From Porous Media, Chemical Engineering Science, 36, 75 85

Lenhard, R.J., Dane, J.H., Parker, J.C, and Kaluarachchi, J.J. (1988); Meaurement and Simulation of One-Dimensional Transient Three-Phase Flow for Monotonic Liquid Drainage, Wat. Resour. Res., 24(6), 853 863

Leverett, M.C. (1941); Capillary Behavior in Porous Solids, Trans. A.I.M.E., 152 169

Mendoza, C.A. and Frind, E.O. (1990a); Advective-Dispersive Transport of Dense Organic Vapors in the Unsaturated Zone 1. Model Development, Wat. Resour. Res., 26(3), 379 387

Mendoza, C.A. and Frind, E.O. (1990b); Advective-Dispersive Transport of Dense Organic Vapors in the Unsaturated Zone 2. Sensitivity Analysis, Wat. Resour. Res., 26(3), 388 398

Mercer, J.W. and Cohen, R.M. (1990); A Review of Immiscible Fluids in the Subsurface: Properties, Models, Characterization and Remediation, J. Contam. Hydrol., 6, 107 163

Miller, C.T., Poirier-McNeill, M.M. and Mayer, A.S. (1990); Dissolution of Trapped Nonaqueous Phase Liquids: Mass Transfer Characteristics, Wat. Resour. Res., 26(11), 2783 2796

Oostrom, M. Hofstee, C., Walker, R.C. and Dane, J.H. (1999); Movement and Remediation of Trichloroethylene in a Saturated heterogeneous Porous Medium 1. Spill Behavior and Initial Dissolution, J. Contam. Hydrol., 37, 159 178

Oostrom, M. and Lenhard, R.J. (1998); Comparison of Relative Permeability- Saturation-Pressure Parametric Models for Infiltration and Redistribution of a Light Nonaqueous-Phase Liquid in Sandy Porous Media, Advances in Water Rsources, 21(2), 145 157

Osborne, M. and Sykes, J. (1986); Numerical Modeling of Immiscible Organic Transport at the Hyde 
Park Landfill, Wat. Resour. Res., 22(1), 25 33

Pantazidou, M. and Sitar, N. (1993); Emplacement of Nonaqueous Liquids in the Vadose Zone, Wat. Resour. Res., 29(3), 705 722

Pinder, G.F. and Abriola, L.M. (1986); On the Simulation of Nonaqueous Phase Organic Compounds in the Subsurface, Wat. Resour. Res., 22(8), 1095 1195

Powers, S.E, Abriola. L.M. and Weber, Jr. W.J. (1994); An Experimental Investigation of Nonaqueous Phase Liquid Dissolution in Saturated Subsurface Systems; Transient Mass Transfer Rates, Wat. Resour. Res., 30(2), 321 332

Powers, S.E, Abriola, L.M. and Weber, Jr. W.J. (1992); An Experimetal Investigation of Nonaqueous Phase Liquid Dissolution in Saturated Subsurface Systems; Steady State Transfer Rates, Wat. Resour. Res., 28(10), 2691 2705

Schroth, M.H., Istok, J.D., Selker, J.S., Oostrom, M. and White, M.D. (1998a); Multifluid Flow in Bedded Porous Media; Laboratory Experiments and Numerical Simulations, Advances in Water Resources, 22(2), 169 183

Schroth, M.H., Istok, J.D. and Selker, J.S. (1998b); Three-Phase Immiscible Fluid Movement in the Vicinity of Textural Interfaces, J. Contam. Hydrol., 32, $1 \sim 23$

Schwille, F (1975); Groundwater Pollution by Mineral Oil Products, IAHS-AISH Publ, 103, 226 240

Schwille, F. (1981); Groundwater Pollution in Porous Media by Fluids Immiscible with Water, The Science of the Total Environment, 21, 173 185

Schwille, F., translated by Pankow, J.F. (1988); Dence Chlorinated Solvents in Porous and Fractured Media, Lewis Publishers, USA

Sleep, B.E. and Sykes, J.F. (1993a); Compositional Simulation of Groundwater Contamination by Organic Compounds 1. Model Development and Verification, Wat. Resour. Res., 29(6), 1697 1708
Sleep, B.E. and Sykes, J.F. (1993b); Compositional Simulation of Groundwater Contamination by Organic Compounds 2. Model Applications, Wat. Resour. Res., 29(6), 1709 1718

Sleep, B.E. and Sykes, J.F. (1989); Modeling the Transport of Volatile Organics in Variably Saturated Media, Wat. Resour. Res., 25(1), 81 92

Thiez, P.Le. and Ducreux, J. (1994); A 3-D Numerical Model for Analyzing Hydrocarbon Migration into Soils and Aquifers, Computer Methods and Advances in Geomechanics, Siriwardane \& Zaman(eds), Balkema, Rotterdam, ISBN9054103809, pp1165 1170

USEPA (1989); Hazardous Waste Treatment, Strorage, and Disposal Facilities (TSDF)- USEPA, OAQPS Air Emmision Models, EPA-45013-87-026, quoted from Todd H. Weidmeir et al. (1999); Natural Attenuation of Fuels and Chlorinated Solvents in the Subsurface, John Wiley \& Sons, Inc. printed in USA

Van Geel, P.J. and Sykes, J.F. (1997); The Importance of Fluid Entrapment, Saturation Hysteresis and Residual Saturations on the Distribution of a Lighterthan-water Non-aqueous Phase Liquid in a Variably Saturated Sand Medium, J. Contam. Hydrol., 25, 249 270

Wang, C.Y. and Cheng, P. (1996); A Multiphase Mixture Model for Multiphase, Multicomponent Transport in Capillary Porous media-1. Model Development, Int. J. Heat Mass Transfer., 39(17), 3607 3618

Wilkins, M.D., Abriola, L.M. and Pennell, K.D. (1995); An Experimental Investigation of Rate-Limited Nonaqueous Phase Liquid Volatilization in Unsaturated Porous Media; Steady State Mass Transfer, Wat. Resour. Res., 31(9), 2159 2172

Yagi, S., Ishii, Y. and Muraoka, K. (1996), Visualization of the Vertical Transportation of VOCs on the Condition of Groundwater Level Fluctuation, Proceeding of Japan Society on Water Environment, the first Kansai branch symposium, 65 66 (in Japanese) 